\title{
TRADE OPENNESS AND TAX STRUCTURE IN MOROCCO: EVALUATION AND IMPACTS
}

\section{SALHI SALAH EDDINE , RITAHI OUSSAMA, ECHAOUI ABDELLAH}

\begin{abstract}
:
In the present work, we seek to empirically assess the effects of trade openness on the Moroccan tax structure. The estimations are covering the period between 1985 and 2019. The results of the modeling using the Two-Stage Least Squares (2SLS) method confirm that the reduction of customs duties has a negative impact on foreign trade revenues, and consequently, on total tax revenues. Also, the reduction in customs duties reduces domestic revenues, notably, value-added tax, and corporate tax. Additionally, it has been shown that not only do the other channels of transmission of trade openness, namely: the liberalization of imports, the promotion of exports, and the variability of the exchange rate, lead to a decrease in trade revenue, but they also bring about an increase in domestic revenue. Finally, the results of the stylized facts and economic modeling allowed us to deduce that the measures taken by Moroccan economic decision-makers to stimulate foreign trade have led to a loss of trade taxes and fiscal injustice.
\end{abstract}

\section{Keywords:}

Trade openness, Tax structure, Customs duties, 2SLS

JEL Classification: $\mathrm{F} 13, \mathrm{H} 20, \mathrm{H} 87$

\section{Authors:}

SALHI SALAH EDDINE , Faculty of law, economics and social sciences, souissi. mohammed v university in rabat., Morocco, Email: salahedinne.salhi@um5r.ac.ma

RITAHI OUSSAMA, Faculty of law, economics and social sciences, souissi. mohammed $v$ university in rabat., Morocco, Email: ritahi.oussama@gmail.com

ECHAOUI ABDELLAH, Faculty of law, economics and social sciences, souissi. mohammed v university in rabat., Morocco, Email: a.echaoui@um5s.net.ma

\section{Citation:}

SALHI SALAH EDDINE , RITAHI OUSSAMA, ECHAOUI ABDELLAH (2021). Trade openness and tax structure in Morocco: evaluation and impacts. International Journal of Economic Sciences, Vol. X(1), pp. 100-127., 10.52950/ES.2021.10.1.007 


\section{Introduction}

In order to join the global economy, developing countries in the last two decades, have put in much effort to liberalize their economies. This international economic transformation has boosted the globalization phenomenon. Indeed, globalization, driven by trade, has increased the competitiveness of external markets, information and technology, capital, labor mobility, world production, and, hence, global economic welfare (Rodrik, 1999).

On the one hand, countries that have liberalized trade have witnessed a reduction or/and elimination of tariffs. On the other hand, the reduction of non-tariff barriers, such as the simplification of customs procedures, import quotas, and quota restrictions, has increased trade taxes. To this end, the relationship between trade liberalization and tax revenues is, mainly, an empirical question as the latter would be related to tax revenues through its effect on foreign trade revenues.

It has been argued that trade liberalization has led to a considerable decrease in trade taxes, and thus, to a decrease in total tax revenues (Khattry and Rao (2002). The fiscal disadvantage is more serious because countries with very high openness continue to heavily rely on trade taxes as a source of government revenue. In this way, countries are forced to increase domestic tax revenues, mainly consumption taxes so as to mitigate the loss of trade revenues (Baunsgaard and Keen, 2009).

In Morocco, economic decision-makers have opted for an irreversible choice of opening up the economy. This process was consolidated by its membership to various organizations and agreements. For example, the GATT in 1987, the World Trade Organization in 1995, the signing of the association agreement with the European Union in 2000, and the free trade agreements with the United States of America in 2006 and other countries ${ }^{1}$. As a result, the openness rate of the Moroccan economy is currently $88.1 \%{ }^{2}$.

This opening has led to the progressive removal of certain tariff barriers that limit trade in the Moroccan economy. The effect of trade liberalization induced by the reduction of customs duties and the increase in free trade agreements has led to a reduction in tax revenues from foreign trade. The trade revenue/GDP ratio has fallen from $3.53 \%$ in 2000 to $0.73 \%$ in 2019 . However, the tax rate on domestic tax revenues remains very high and still on an upward trend. The latter has averaged around $22.1 \%$ of GDP and remains concentrated on the middle class and a limited number of Moroccan companies.

The rate of taxation of the Moroccan economy has exceeded the optimal rate, and this has led to fiscal distortions. Consequently, this has given rise to budgetary instability which in turn increases budget deficits and makes them structural. Thus, critics have questioned the use of tariffs as they risk weakening the state's tax base, which is already financially strained.

\footnotetext{
1 The other free trade agreements are the agreement with the countries of the line of Arab States (1998), the agreement with the United Arab Emirates (2003), the agreement with Turkey (2006) and the Agadir agreement (2007).

2 Data published by the Ministry of Economy and Finance of Morocco (2019).
} 
Given the importance of trade taxation as an essential base for the state budget, the following question arises: To what extent does trade openness affect the Moroccan tax structure? Regardless of the studies that have been carried out on taxation, this research question has received, to our knowledge, almost no empirical attention on the structure of Moroccan tax revenues. Thus, in this study, we diversify the instruments for measuring trade liberalization. Contrarily to other international works, which are limited to customs tariffs and the rate of openness, our study has added other transmission channels through which trade openness affects the tax structure of the Moroccan economy.

The main objective of this study is to evaluate the effects of trade opening on the Moroccan tax structure. Our work is based on the following four research hypotheses:

H1: Trade openness, induced by the decrease in customs duties, leads to a decrease in foreign trade revenues, and consequently, in total tax revenues.

H2: Greater trade openness leads to higher levels of import demand, and, therefore, higher domestic tax revenues.

H3: Exports exert a positive effect on trade revenues through the export revenue channel.

H4: A devaluation of the national currency leads to lower trade taxes and, possibly, higher domestic tax revenues.

Our study will be divided into four parts. The first part deals with the literature review on the relatioship between trade openness and tax revenues. The second part is devoted to the presentation of stylized facts. The research methodology and data sources of this study are presented in the third part. The last part tackles both the results and discussion.

\section{Literature review}

The literature on the impact of trade liberalization on tax revenues is very abundant. In this section, we provide a literature review of the various works that deal with the relationship between trade openness and tax revenues.

\subsection{Trade openness and tax revenues}

Economic theory has defined international trade as one of the most important structural determinants for governments to raise revenue. The foreign trade sector is an important source of tax revenue. Several empirical studies - cited below - have been carried out to assess its effects.

The nature of trade makes the foreign trade sector an easy sector to tax. Stotsky and WoldeMariam (1997) pointed out that the characteristics of this sector make it more likely to be taxed compared to other domestic economic activities. Bornhorst, Gupta, and Thornton (2009) and Drummond, Daal, Srivastava, and Oliveira (2012) argued that economies can easily generate taxes at the border. For example, trade openness may also lead to higher wages ${ }^{3}$ for employees of firms oriented towards foreign trade, and consequently, to higher direct and indirect taxes. The

\footnotetext{
${ }^{3}$ Trade openness allows for increased productivity and more sustained economic growth.
} 
authors also demonstrated that if trade liberalization reflects an increase in imports, it may generate higher trade taxes. Similarly, the relative price ${ }^{4}$ decline induced by the international situation is transmitted directly from domestic producers to consumers ${ }^{5}$. The latter witness an increase in their purchasing power and, thus, their consumption both locally and in imports. As a result, the revenue from consumption tax and import tariffs would increase. Similarly, the decrease in international prices on imported products leads to a decrease in costs for producers, especially for enterprises operating in the foreign trade sector. Within this framework, domestic commercial firms operating in the informal economy will now be motivated to enter the formal economy to take advantage of the lower costs used in the production process. Thus, firms operating in the formal economy would be motivated to stay to take full advantage of the fall in prices. In this case, the government would be able to generate the maximum possible tax revenue from the formal sector and from new informal enterprises entering the formal sector. As a result, this situation makes it possible to increase the level of national production thanks to the very high value-added of both sectors.

In a study on sub-Saharan African countries, Agbeyegbe, Stotsky, and WoldeMariam (2006) investigated the relationship between trade openness, the exchange rate, and tax revenues. The authors analyzed a panel of 22 countries using the Generalized Method Of Moments (GMM) over the period starting from 1980 to 1996 . The results of the study have shown that trade openness has no effect on total tax revenues and is positively small on trade taxes. They also found that the exchange rate does not affect tax revenues.

Another study by Khattry and Rao (2002) sought to assess the effect of trade liberalization on tax revenues. The study covered a panel of 81 developing countries during the period 1978 and1999. The results indicate that trade openness has a negative effect on total tax revenues and tax revenues from foreign trade. The decrease in trade taxes is explained by the reduction of tariffs. This liberalization policy is related to the inability of the state to generate domestic tax revenues. This results in a decrease in total tax revenues and an increase in the debt-to-GDP ratio.

A study prepared by the Economic Commission for Africa (ECA, 2004) revealed that trade openness causes fiscal instability in African countries. This instability is linked to the dependence of these economies on taxes on international trade. The Generalized Method of Moments (GMM) was applied to a panel of African countries during the period of 1980 and 2012. The main conclusion of the study was that the decline in trade taxes can be compensated for by the increase in domestic revenues, especially value-added tax (VAT).

Khattry (2003) studied the relationship between trade liberalization and income compression. He concluded that trade liberalization leads to revenue losses and increases the budget deficit. The latter is overcome by either reducing public expenditure or financing the deficit through internal and external borrowing, which increases public debt. The increase in debt leads to an increase in debt interest payments and, thus, to a new budget deficit. The public authorities find themselves in a vicious circle of budget deficits.

\footnotetext{
${ }^{4}$ International prices on imported products.

5 This drop in prices benefits producers and consumers in importing countries.
} 
Keen and Ligthart (2002) demonstrated that trade liberalization through tariff reduction changes the fiscal structure of developing countries. The authors show that tariff reduction has a positive and significant impact on domestic taxation (income tax and consumption taxes on goods and services), yet it reduces trade taxes. They explained that trade liberalization increases real consumer income as a result of lower international prices for goods and services. However, in developing countries, it does not improve the trade tax base. This indicates that trade liberalization in developing countries allows a move away from trade taxation and compensates for the loss of trade taxes by increasing income and consumption taxes. These results confirm the arguments of Hatzipanayotou et al (1994) that replacing tariffs with domestic taxation improves welfare, yet leads to fiscal injustice.

Baunsgaard and Keen (2005) examined the issue of offsetting trade taxes with domestic tax revenues. They took a panel of 125 countries for the period 1975 and 2000. The authors concluded that trade liberalization in low-income countries does not recover lost tax revenues. While middle-income countries have an average recovery from the loss of trade taxes, highincome countries have a very high recovery rate. Also, the authors argued that developing countries have a high dependence on indirect taxes because they are very easy to impose, especially tariffs and duties. In this case, governments opt for a policy of liberalization through lowering tariff barriers, but resulting in a deficit in tax revenues. Knowing that the public authorities cannot find a comfortable way to compensate for the loss of tax revenues, they resort to internal and external borrowing to reduce the budget deficit. Resorting to borrowing increases the interest payments on the debt, and thus, the vicious circle of the budget deficit goes on.

Ebrill et al (1999) assessed the impact of trade liberalization on foreign trade revenues. The authors found out that trade liberalization reduces trade taxes. They explained that a decrease in the tariff rate leads to a decrease in trade revenues if the price elasticity of demand and supply is less elastic.

Keen and Simone (2004) showed that trade liberalization has a negative impact on tax revenues in the event of a tariff cut. On the other hand, they argued that trade openness can have a positive effect on tax revenues if it reflects a reduction in non-tariff barriers such as simplification of customs procedures, restriction of import quotas, and lower tariff rates. Rodriguez and Rodrik (1999) also pointed out that there is a positive link between trade openness and tax revenues while highlighting the role of the state (the quality of institutions) in a more liberalized trade environment.

In another study, Aizenman and Jinjarak (2009) examined the impact of globalization on tax revenues of countries at different levels of development. The results of the study show that the process of globalization allows for greater trade and financial integration. Besides, they found out that trade and financial liberalization has a negative effect on tax revenues. They explained this decline by the low institutional quality of countries and the high weight of the informal sector.

Enrico Longoni (2009) studied the impact of trade liberalization on trade taxes in a sample of African countries from 1970 to 2000. Using the Generalized Method of Moments (GMM), the author found out that there is a trade-off between greater trade openness and the revenues collected from import and export taxes. Furthermore, Longoni suggests that there is a non-linear 
relationship between trade taxes and trade openness resulting in a Laffer effect. Thus, the author indicated that tariff dismantling and free trade have a negative effect on tax revenues.

Hisali (2012) examined the relationship between customs duties and trade policy-induced reforms in Uganda. The author argued that exchange rate devaluation affects domestic market prices for the consumption of imported goods, which increases trade revenues in the short run but decreases them in the long run.

Epaphra (2014) assessed the relationship between trade openness and import duties in Tanzania. The empirical results show that trade openness acts positively on customs revenue. Exchange rate depreciation had a negative impact on trade tax revenue.

Karimi et al,. (2016) examined the impact of trade liberalization and trade tax revenues. The study is based on a sample of 103 developing countries during the period 1993-2012. The authors prove a non-linear Laffer effect relationship between trade openness and trade taxes. Thus, they find a negative relationship between the two economic variables as governments passed on the loss of trade taxes to domestic revenues.

In another recent study, Sèna Kimm Gnangnon (2017) studied the effect of multilateral trade liberalization on government revenues for a panel data set covering 169 countries from 1995 to 2013. The results of the study reveal that the effect is positive depending on the development level of countries and domestic trade policy. The author emphasized the importance for WTO members to promote multilateral trade while pointing out the fact that restrictive domestic trade policies undermine multilateral efforts, and will, therefore, weaken government revenues.

Ahmed and Ali (2018) analyzed the effect of trade liberalization on Pakistan's trade revenue. They used modeling based on the Laffer curve. The results of the study reveal a negative impact of trade openness on tax revenue.The work also concludes the existence of an inverted $U$ function between the two variables studied.

\subsection{Trade openness and direct taxes}

The literature on the structure of tax revenues indicates that direct taxes are composed of corporate and personal income taxes. The relationship between trade openness and direct taxes is driven by economic growth. Several researchers have examined this relationship [Frankel and Romer (1999); Ebrill et al (1999); Tanzi (1987)]. The authors studied the effect of trade openness on income taxes while applying the gravity model. The results of the study show that openness increases direct tax revenues significantly. This increase is related to very high economic growth which is capable of raising income taxes.

Addison and Levin (2006) also used the gravity model to study the relationship between trade openness and direct taxes. The authors confirmed the idea that the volume of trade leads to increased economic growth, and, consequently, to increased mobilization of direct tax revenues. This economic growth has a positive effect on the level of development resulting in higher per capita income, which, in return, has an impact on the broadening of the income tax base. 
Tanzi (1987) provided a sound design while arguing that there is a causal relationship between the tax rate and per capita income. The author argued that an increase in per capita income leads to an increase in the size of the public sector, which in turn leads to an increase in the tax base.

Baunsgaard and Keen (2009) found that there is a positive relationship between economic growth and the tax rate. The results of their study show that per capita income has a positive impact on the rate of the total tax burden. Although this impact is not strong, the estimate indicates that per capita income has a positive impact on personal income tax.

Othieno and Shinyekwa (2011) pointed out that in the East African Community, income tax can be difficult to mobilize. This difficulty lies in structural constraints, administrative costs, and low sanctions against tax evasion and corruption. As a result, personal taxation remains focused on employees, and small and medium-sized enterprises. These factors lead to a lower tax base for income tax, which makes the tax base narrower in this community; and, hence, a reduction in this type of tax takes place, independently of efforts to open up trade.

\subsection{Trade openness and indirect taxes}

The economic literature on the structure of tax revenues indicates that indirect taxes are composed of value-added tax (VAT) and taxes on foreign trade. According to Addison and Levin (2006), the relationship between consumption tax and trade openness is more complicated to assess. The authors argued that the effects of trade openness on indirect tax revenues are related to certain factors, notably the price elasticity of import demand and the price elasticity of import supply. They also showed that reducing import tariffs lowers the relative prices of imports relative to import substitutes. This encourages the national consumer to consume more imported products. Consequently, this leads to a decrease in taxes levied on import substitutes and an increase in taxes on imports.

Thus, the impact of trade opening on indirect taxes can be seen through its effect on economic growth. The indirect tax base increases as the level of economic growth increases. Indeed, the increase in economic growth leads to an increase in consumption; consequently, the consumer should have more income, which in turn affects his purchasing power and results in a high increase in domestic demand. This situation allows the tax base for a consumption tax to be broadened.

To conclude, from the above literature, it can be deduced that the impact of trade opening on tax revenues is an empirical question. The results of the works are mixed; while some results suggest that the effects are negative, other studies argue for positive effects. This can be explained by the structure of the economies, the level of development, external competitiveness, and tax reforms, etc. Econometrically speaking, however, the study period, the methodology, and the choice of variables are other aspects that can explain the differences in the above results.

\subsection{Other determinants of tax revenues}

In addition to the factors discussed in the above-mentioned studies, tax revenues are affected by other important determinants; mainly the level of economic development, the structure of production, and the socio-demographic factors. Lozt and Morss (1967) are the pioneers who 
pointed out that the level of development, as measured by GDP per capita, is the most frequently used factor explaining tax revenues. The authors showed that countries with high per capita income tend to collect more tax revenue. On the other hand, Stotsky and WoldMariam (1997) argued that countries that have a very high share of agriculture in national production may have a tax disincentive. On the other hand, Bahl (2003) pointed out that while urbanization increases state revenues, increasing population density leads to losses in tax revenues and prevents governments from detecting new taxpayers.

\section{Stylized facts}

This part of the study is devoted to examining the evolution of trade openness and its relationship with the tax structure. Such an exercise should strengthen the understanding of the transmission channels through which trade openness affects Moroccan tax revenues.

\subsection{Evolution of customs duty revenues}

Since the 1980s, Morocco's foreign trade has been conditioned by the policy of tariff protection. This is in light of the fact that in 1985, the rate of customs duties recorded $15.6 \%$. Protectionism has continued to collect customs revenue for the state budget. As illustrated in the graph below, and during the period 1985-1998, the average rate of customs resources is around $14.56 \%$.

Figure 1: Evolution of the rate of customs revenue

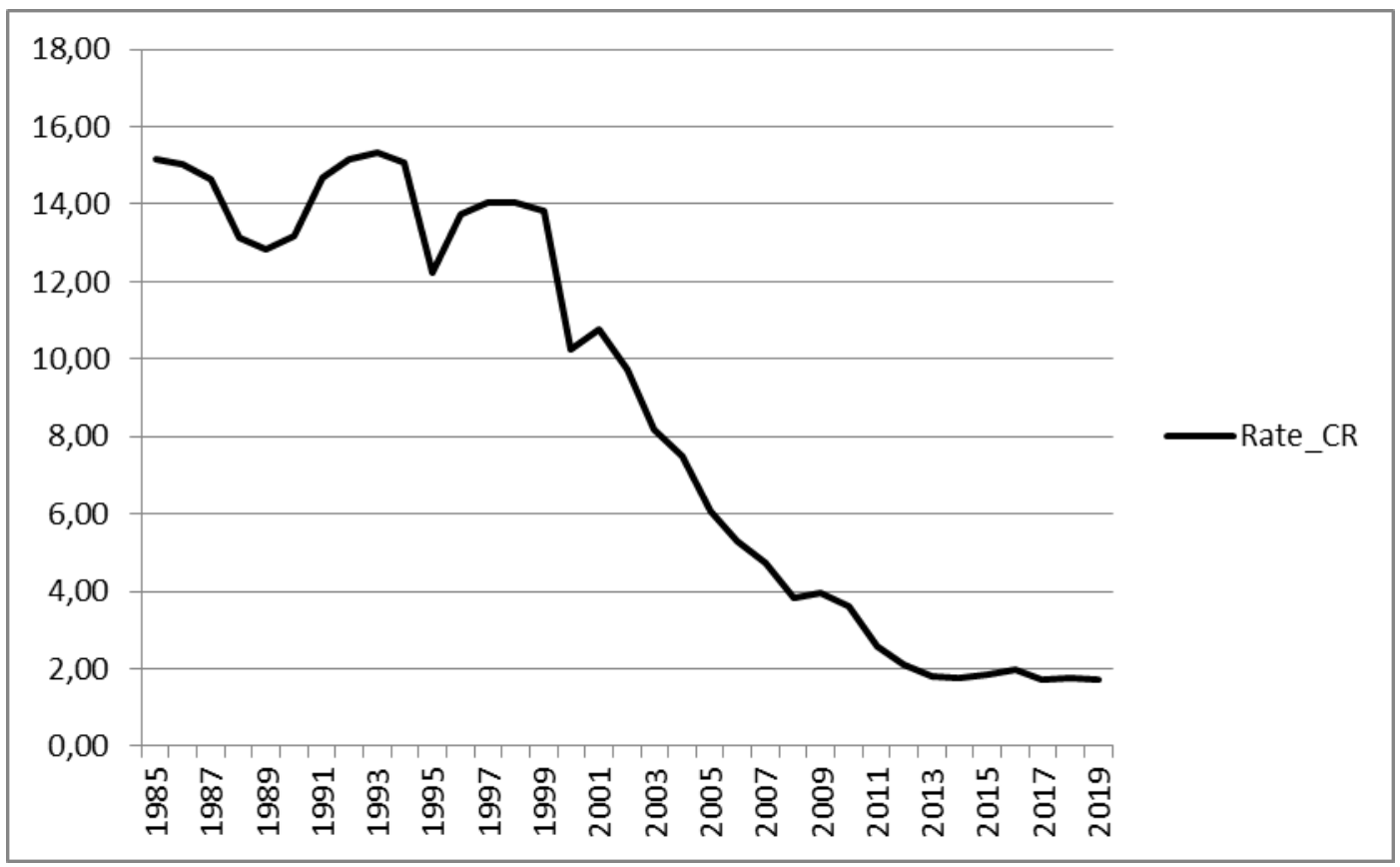

Source: Elaboration of authors based on data from the Ministry of Economy and Finance Morocco

On the other hand, the beginning of the 1990s marked a real change in Morocco's trade policy, especially with its membership to the WTO in 1995. In fact, the entry into force of the free trade agreements allowed a drop in customs tariffs from 2000 onwards. The rate of customs revenue fell from $10.24 \%$ in 2000 to $1.74 \%$ in 2019 . The process of trade liberalization has modified the instruments of tariff protection policy. Within this framework, the Moroccan public authorities have 
undertaken tariff policies characterized by a gradual dismantling of tariff and non-tariff measures with a view to their elimination.

The policy of trade openness, induced by the dismantling of tariffs, has brought about a profound change aimed at the liberalization of imports and the promotion of exports. To this end, trade flows have increased considerably as shown in graph (2). The abandonment of the General Import Programme (PGI) and the promulgation of Law 13-39 on foreign trade have favored international economic relations between Morocco and its trading partners.

Figure 2: Evolution of openness indicators

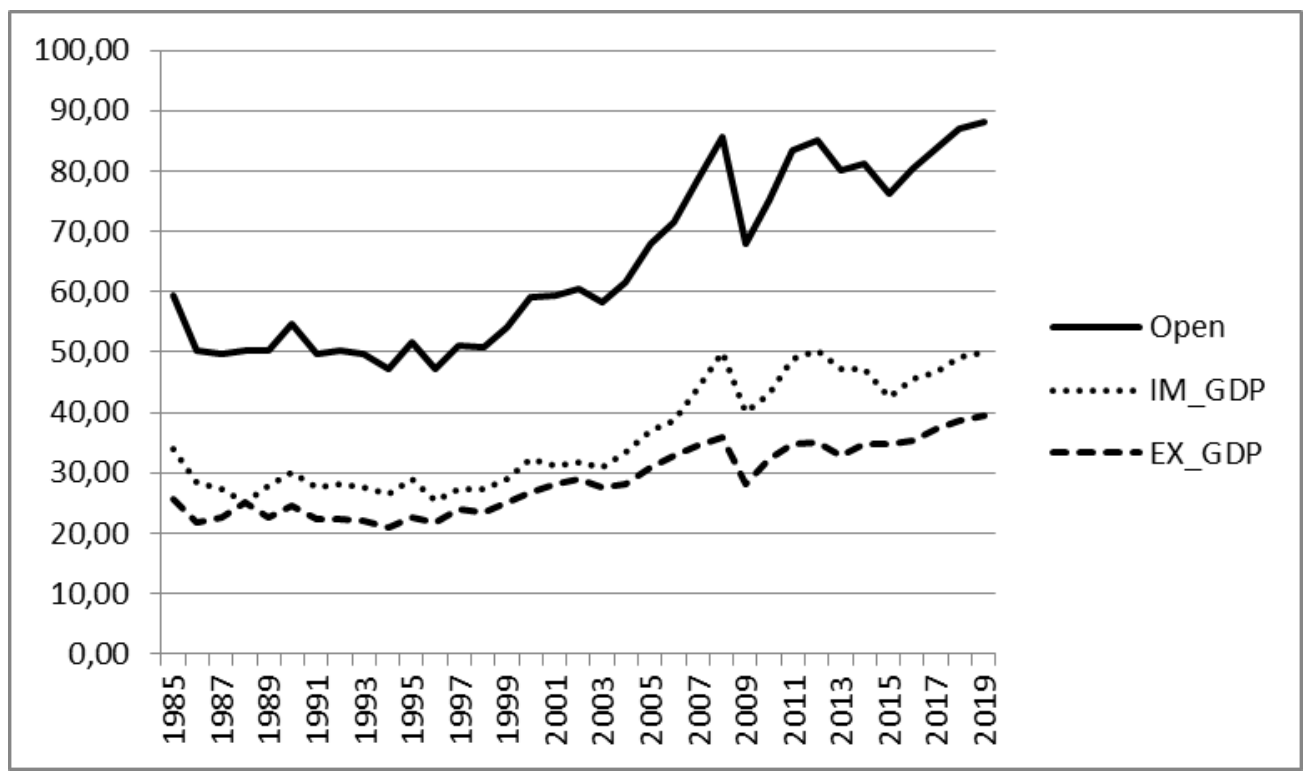

Source: Elaboration of authors based on data 6 from the Ministry of Economy and Finance Morocco

Later, the free trade agreements that were signed between Morocco, the EU and other countries further lifted remaining trade restrictions and controls by, notably, gradually reducing tariffs. As a result, while import duties have almost halved, trade flows have considerably increased. The openness of the Moroccan economy has increased from $59.3 \%$ in 1985 to $88.10 \%$ in 2019 . This trading dynamic has also led to an increase in the volume of imports and exports as the share of imports in GDP is $49.8 \%$ in 2019 compared to $33.8 \%$ in 1985 . Similarly, the export effort has undergone an upward trend during the period of $1985-2019$, rising from $25.5 \%$ in 1985 to $39.4 \%$ in 2019. Despite this upward trend in trade flows, the level of exports has remained below imports, which illustrates a structural trade deficit. The underperformance of exports is mainly explained by the low quality of the Moroccan exportable offer, the low level of innovation in the world trades, and the unskilled labor force.

\subsection{Evolution of the main tax revenues}

Morocco has undergone numerous tax reforms in recent years which have contributed to the increase in tax revenues. The evolution of taxes as a percentage of GDP between 1985 and 2019

\footnotetext{
${ }^{6}$ https://www.finances.gov.ma/fr/Pages/statistiques-economiques-financieres.aspx.
} 
shows a significant increase in the tax burden on taxpayers. Graph (3) reveals that the evolution of the different taxes in Morocco remains concentrated on income tax, VAT and corporation tax. VAT shows a decrease during the period 1985-1990. This is due to the drought which affected consumer goods, and, consequently, the fall in household purchasing power. This represents an average contribution to GDP of 3.98\%. From 2003 onwards, we note that the value added tax shows a significant upward trend compared to other taxes. This is explained by the performance of VAT on imported products and the improvement in gross national income per capita. This represents an average contribution to GDP of $8.75 \%$.

Figure 3: Evolution of tax revenues as \% of GDP

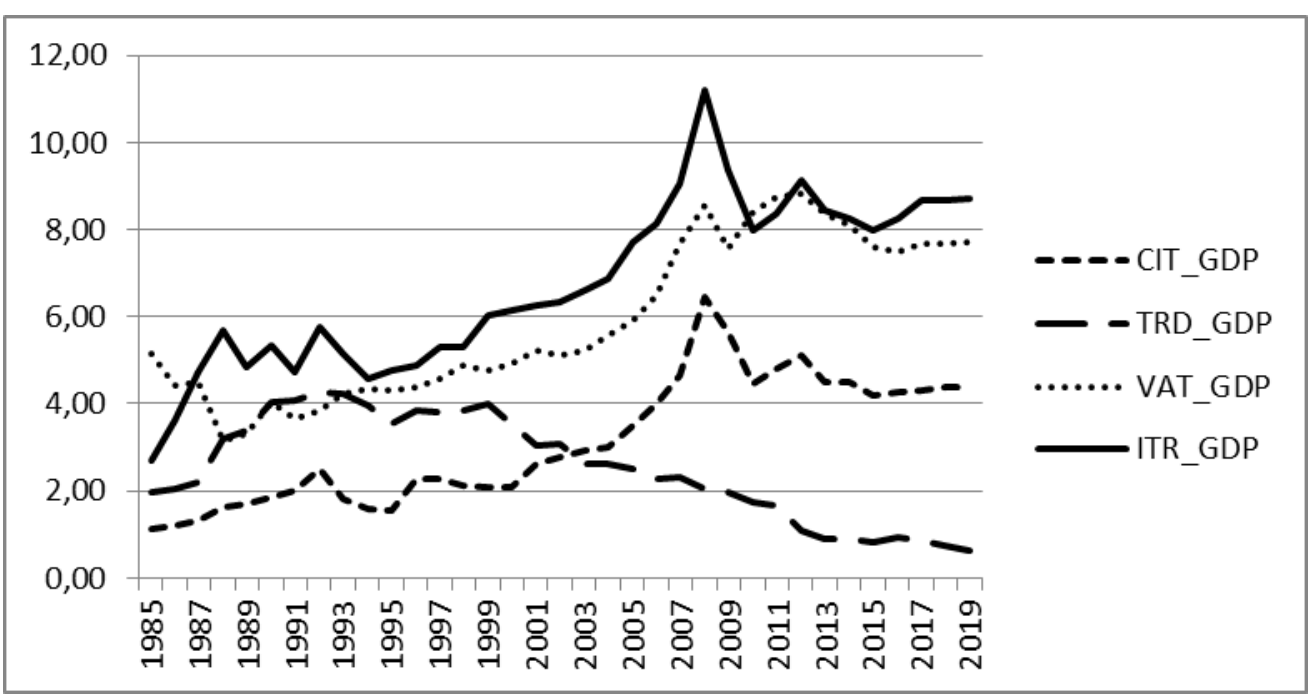

Source: Elaboration of authors based on data from the Ministry of Economy and Finance of Morocco

Regarding income tax, we note the superiority of the latter over corporate tax. As a matter of fact, during the period lasting from 1985 to 1990 , income tax was dominated by the presence of certain taxes (deduction from wages and salaries, tax on real estate profits, tax on participation in national solidarity, etc...) with a share of $6.56 \%$ in the GDP. On the other hand, the corporate tax which was introduced in 1987 remains concentrated on the profits and profiles of the large and medium-sized firms with a share of $1.39 \%$ in the GDP. In 1990, the public authorities carried out a reform while introducing the overall taxable income; the final income tax reform took place in 2006. Such a tax reform allowed for increased mobilization of income tax revenues. The spike in 2008 was due to the intervention of the tax administration. The latter reinforces these efforts in terms of tax control and the declaration process.

The most important finding in our study relates to the trend in foreign trade revenues. We can clearly see that the latter were high during the period between 1985 and 1999, with an average of $3.64 \%$ in the GDP. In other words, this rise was because of the policy of tariff protection. On the other hand, from 2000 onwards, the evolution of trade revenues shows a downward trend. This means a contribution of $0.73 \%$ to GDP in 2019. The signing of free trade agreements and customs restrictions are at the origin of the decline in the trade tax base. Through this analysis, we can, a priori, deduce the observation of fiscal injustice since the decrease in trade taxes is compensated by the increase in national taxes, mainly VAT and income tax. 


\subsection{Evolution of the real effective exchange rate}

Before proceeding with the empirical evaluation of the effect of exchange rate variability on tax revenues, we recall that Morocco has a conventional fixed exchange rate regime with the composition of the basket weighted according to the respective weights (60\% Euro and $40 \%$ USD).

Repetitive devaluation policies were carried out during the 1980s and early 1990 s to counter the overvaluation of the dirham and, thus, contribute to the absorption of external deficits. However, despite this policy, the dirham accumulated a depreciation, which favored exports and made imports very expensive. Consequently, this situation pushed the monetary authorities to abandon these devaluation policies. The structure of the basket weighting has been modified several times in order to better hold the structure of trade and the exchange rate risk.

Figure 4: Evolution of the real effective exchange rate

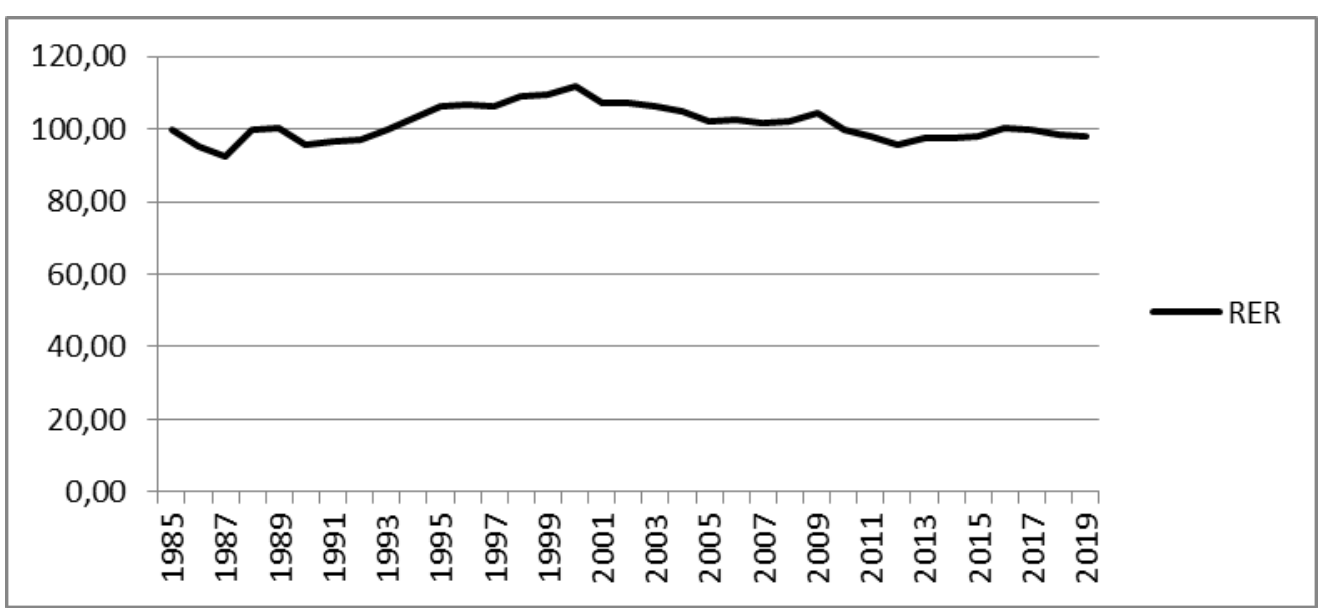

Source: Elaboration of authors based on data from the Ministry of Economy and Finance of Morocco

The results of the stylized facts have given us an insight into the trend of the variables of trade liberalization and the structure of Moroccan tax revenues. However, to achieve our goal, an econometric modeling is needed as impact studies can shed light on the true sign of the explanatory variables, especially when they are submitted in interaction with others.

\section{Methodological framework}

The literature review allowed us to look at the explanatory variables that could explain the level of tax revenues. In this part of the work, we present the econometric specification of the different models to be estimated, the data source, and the estimation method.

\subsection{Model specification and data source}

The econometric specification of our basic model is as follows:

$$
\text { TTR_GDP } P_{t}=\alpha_{0}+\alpha_{1} X_{t}+\alpha_{2} \text { OPEN }_{t}+\varepsilon_{t}
$$

Where: 
TTR_GDP: Tax revenue as \% of GDP.

$\mathrm{X}$ : Vector of the explanatory variables. These are the control variables, and they translate the level of the tax base generated by the contributive capacity of the Moroccan economy in terms of production and economic development.

OPEN: Vector which captures the effect of the transmission channels of trade openness.

$\varepsilon$ : The error of specification.

As mentioned at the beginning of the study, the added value of this work lies in diversifying the channels of transmission of the trade openness ${ }^{7}$. To this end, we integrate, as channels, the rate of customs duties, the rate of trade openness, the share of imports in GDP, the export effort, and variability of the real effective exchange rate. Thus, in relation to another work which is limited to total tax revenues, we have decided to study the tax structure. In other words, we evaluate the effect of trade openness on Morocco's main tax revenues, notably CIT, ITR, VAT, and trade tax revenue. This makes it possible to deal with the effect on each type of tax, on the one hand, and, to ensure a robust econometric specification of the results obtained, on the other.

So, the econometric specifications to be estimated are as follows:

$$
\begin{aligned}
& \text { TTR_GDP }=\alpha_{0}+\alpha_{1} \operatorname{LogGDP}_{\mathrm{t}}+\alpha_{2} \text { Agr_GDP }_{\mathrm{t}}+\alpha_{3} \text { Ind_GDP }_{\mathrm{t}}+\alpha_{4} \mathrm{PD}_{\mathrm{t}}+\alpha_{5} \mathrm{Urb}_{\mathrm{t}}+\alpha_{6} \mathrm{ESE}_{\mathrm{t}} \\
& +\alpha_{7} C D_{t}+\alpha_{8} \text { Open }_{\mathrm{t}}+\alpha_{9} \mathrm{IM}_{-} \mathrm{GDP}_{\mathrm{t}}+\alpha_{10} \mathrm{EX}_{-} \mathrm{GDP}_{\mathrm{t}}+\alpha_{11} \mathrm{VRER}_{\mathrm{t}}+\varepsilon_{\mathrm{t}} \\
& \text { CIT_GDP }=\alpha_{0}+\alpha_{1} \operatorname{LogGDP}_{\mathrm{t}}+\alpha_{2} \text { Agr_GDP }_{\mathrm{t}}+\alpha_{3} \text { Ind_GDP }+\alpha_{4} \mathrm{PD}_{\mathrm{t}}+\alpha_{5} \mathrm{Urb}_{\mathrm{t}}+\alpha_{6} \mathrm{ESE}_{\mathrm{t}} \\
& +\alpha_{7} C D_{t}+\alpha_{8} \text { Open }_{\mathrm{t}}+\alpha_{9} \mathrm{IM}_{-} \mathrm{GDP}_{\mathrm{t}}+\alpha_{10} \mathrm{EX}_{-} \mathrm{GDP}_{\mathrm{t}}+\alpha_{11} \mathrm{VRER}_{\mathrm{t}}+\varepsilon_{\mathrm{t}} \\
& \text { ITR_GDP }=\alpha_{0}+\alpha_{1} \text { LogGDP }_{\mathrm{t}}+\alpha_{2} \text { Agr_GDP }_{\mathrm{t}}+\alpha_{3} \text { Ind_GDP }_{\mathrm{t}}+\alpha_{4} \mathrm{PD}_{\mathrm{t}}+\alpha_{5} \mathrm{Urb}_{\mathrm{t}}+\alpha_{6} \mathrm{ESE}_{\mathrm{t}} \\
& +\alpha_{7} C D_{t}+\alpha_{8} \text { Open }_{\mathrm{t}}+\alpha_{9} \text {IM_GDP }_{\mathrm{t}}+\alpha_{10} \text { EX_GDP }_{\mathrm{t}}+\alpha_{11} \mathrm{VRER}_{\mathrm{t}}+\varepsilon_{\mathrm{t}} \\
& \text { VAT_GDP }=\alpha_{0}+\alpha_{1} \operatorname{LogGDP}_{\mathrm{t}}+\alpha_{2} \mathrm{Agr}_{-} \mathrm{GDP}_{\mathrm{t}}+\alpha_{3} \text { Ind_GDP }_{\mathrm{t}}+\alpha_{4} \mathrm{PD}_{\mathrm{t}}+\alpha_{5} \mathrm{Urb}_{\mathrm{t}}+\alpha_{6} \mathrm{ESE}_{\mathrm{t}} \\
& +\alpha_{7} C D_{t}+\alpha_{8} \text { Open }_{\mathrm{t}}+\alpha_{9} \text {IM_GDP }_{\mathrm{t}}+\alpha_{10} \text { EX_GDP }_{\mathrm{t}}+\alpha_{11} \mathrm{VRER}_{\mathrm{t}}+\varepsilon_{\mathrm{t}} \\
& \text { TRD_GDP }=\alpha_{0}+\alpha_{1} \operatorname{LogGDP}_{\mathrm{t}}+\alpha_{2} \mathrm{Agr}_{-} \mathrm{GDP}_{\mathrm{t}}+\alpha_{3} \text { Ind_GDP }_{\mathrm{t}}+\alpha_{4} \mathrm{PD}_{\mathrm{t}}+\alpha_{5} \mathrm{Urb}_{\mathrm{t}}+\alpha_{6} \mathrm{ESE}_{\mathrm{t}} \\
& +\alpha_{7} C D_{t}+\alpha_{8} \text { Open }_{\mathrm{t}}+\alpha_{9} \text { IM_GDP }_{\mathrm{t}}+\alpha_{10} \text { EX_GDP }_{\mathrm{t}}+\alpha_{11} \mathrm{VRER}_{\mathrm{t}}+\varepsilon_{\mathrm{t}}
\end{aligned}
$$

Our study covers the period between 1985 and 2019. We use the Two-Stage Least Squares (2SLS) method to estimate the above specifications.

The data used in this modeling are derived from two data sources. The macroeconomic control variables come from the World Bank databases. The data on tax revenues come from the International Monetary Fund (IMF) database.

The modeling of the effect of trade openness on the structure of Moroccan tax revenues is carried out according to the following steps:

\footnotetext{
${ }^{7}$ The table in appendix 3 presents in detail the channels transmission of trade opennes.
} 
- Estimation of econometric models

- Statistical validation of the robustness of the estimators (multicollinearity, endogeneity, the validity of the instruments...)

- Interpretation of the obtained results

- Future recommendations

The following table shows the title of each variable chosen and its expected sign:

Table 1: Variables used in the regression models

\begin{tabular}{|c|c|c|}
\hline Variables & Title & Expected sign \\
\hline \multicolumn{3}{|c|}{ Endogenous Variables } \\
\hline TTR_GDP & Total tax revenues, percent of GDP & - ---------- \\
\hline CIT_GDP & Corporate income tax revenue, percent of GDP & 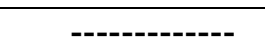 \\
\hline ITR_GDP & Income tax revenue, percent of GDP & ------------ \\
\hline VAT_GDP & VAT tax revenue, percent of GDP & 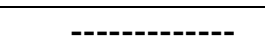 \\
\hline TRD_GDP & Trade tax revenue, percent of GDP & ------------ \\
\hline \multicolumn{3}{|c|}{ Control variables } \\
\hline GDP & GDP per capita & $(+)$ \\
\hline Agr_GDP & The added value of the agricultural sector/GDP & $(-)$ \\
\hline Ind_GDP & The added value of the industrial sector/GDP & $(+)$ \\
\hline$\overline{E S E}$ & Enrolment in secondary education & $(+)$ \\
\hline PD & Population density (person per $\mathrm{Km}^{2}$ ) & $(-)$ \\
\hline Urb & $\begin{array}{l}\text { Urbanization: the share of the urban population in the } \\
\text { total population }\end{array}$ & $(+)$ \\
\hline \multicolumn{3}{|c|}{ Variables associated with the effect of trade openness } \\
\hline CD & The rate of customs duties & $(-)$ \\
\hline Open & Trade openness, percent of GDP & $(-)$ \\
\hline IM_GDP & The share of imports in GDP & $(-)$ \\
\hline EX_GDP & The share of exports in GDP (the export effort) & $(+)$ \\
\hline VRER & Variability of the real effective exchange rate & $\begin{array}{c}\text { ? ambiguous } \\
\text { effect }\end{array}$ \\
\hline
\end{tabular}

Source: Elaboration of authors

\subsection{Estimation method}

When modeling economic phenomena, a natural question to ask is whether a variable presumed to be endogenous - in previously adapted models - could instead be treated as exogenous. The variable trade openness and its transmission channels are endogenous, and we attempted to resolve this problem with an estimation technique using instrumental variables.

In the case of endogenous explanatory variables, the OLS estimator is no longer efficient insofar as the regressors are correlated with the error term. To decipher this hypothesis violation issue, we use the Two-Stage Least Squares (2SLS) estimator, which consists of identifying the endogenous variable while associating it with a set of instruments deemed robust.

The problem of the endogeneity of the degree of openness has also been studied in the literature. Frankel and Romer (1999), and Feyrer (2009) proposed the procedure of instrumental variables while using the geographical characteristics of bilateral trade. The authors created an index, as 
an instrumental variable, based on geographical characteristics using information from the gravity model of international trade.

In this study, we adopt the same technique as these authors. However, since our study focuses on the case of the Moroccan economy and not a panel of countries, it would be very difficult to construct this index. For this purpose, we take proxy variables to measure the geographical characteristics of Morocco's bilateral trade.

These proxy variables will allow us to instrument the degree of openness which, according to the literature, is endogenous due to its inverse causal relationship with tax revenues. We use the instruments of Feyrer (2009):

- Transport costs

- Territorial surface area

- Settler mortality

The method of estimation by instrumental variables consists of the first step of estimating the models by 2SLS. The second stage is devoted to the test of endogeneity via the Wu-Hausman test. The last step is devoted to the validity of the instruments via the Sargan test.

\section{Results and discussions}

This part of the work attempts to present the results of estimating the effect of trade openness on the main tax revenues. The aggregation of all tax resources hides the real effect of trade liberalization, which should be examined by analyzing instead the different types of taxes. There are five specifications whose dependent variables are: total tax revenue, corporate tax, income tax, value-added tax, and trade tax.

Before modeling, we need to ensure that there is no correlation between the explanatory variables. The correlation matrix (Annex 1 ) shows that there is a problem of multicollinearity between the variables that measure trade openness as well as between these variables and GDP per capita. To address this problem, we carry out an alternative estimation, a stepwise regression.

We used different types of specification to ensure the robustness of our results. The following tables present the results of the impact of trade openness on total tax revenue and foreign trade. The detailed results on the impact of openness on other tax revenues are presented in appendix 4.

\subsection{Statistical interpretation}

The models are globally significant and have a good fit since the coefficients of determination are important. The probabilities for the Wu-Hausman test are less than $5 \%$ in all specifications. Therefore, we reject the hypothesis $\mathrm{H} 0$ (the variable is exogenous) and we accept $\mathrm{H} 1$ (the variable is endogenous). The test confirms well the endogeneity status of the trade openness variable. 
The Sargan's test is a test that verifies the over-identification restrictions. The hypothesis it tests is that instrumental variables are not correlated to a set of residuals and are, therefore, acceptable instruments. We note that the probabilities associated with the Sargan test are greater than $5 \%$, and we, therefore, accept $\mathrm{HO}$ (the instruments are valid).

Table 2 : Trade openness and Total tax revenues

\begin{tabular}{|c|c|c|c|c|c|}
\hline \multicolumn{6}{|c|}{$\begin{array}{l}\text { The dependent variable: Total tax revenues/GDP } \\
\text { Estimator: } 2 S L S\end{array}$} \\
\hline Specifications & (1) & (2) & (3) & (4) & (5) \\
\hline LogGDP & $\begin{array}{c}9,683 \\
(0,004)^{\star * *}\end{array}$ & $\begin{array}{c}6,487 \\
(0,001)^{* * *}\end{array}$ & $\begin{array}{c}6,751 \\
(0,001)^{\star * *}\end{array}$ & $\begin{array}{c}6,425 \\
(0,000)^{\star * *}\end{array}$ & $\begin{array}{c}6,705 \\
(0,043)^{* *}\end{array}$ \\
\hline Agr_GDP & $\begin{array}{c}-0,940 \\
(0,005)^{\star \star \star}\end{array}$ & $\begin{array}{l}-0,202 \\
(0,323)\end{array}$ & $\begin{array}{c}-0,788 \\
(0,069)^{*}\end{array}$ & $\begin{array}{c}-0,800 \\
(0,051)^{\star *}\end{array}$ & $\begin{array}{c}-0,351 \\
(0,071)^{*}\end{array}$ \\
\hline Ind_GDP & $\begin{array}{c}0,888 \\
(0,294)\end{array}$ & $\begin{array}{l}-0,742 \\
(0,034)^{* *}\end{array}$ & $\begin{array}{l}-1,048 \\
(0,012)\end{array}$ & $\begin{array}{c}-0,574 \\
(0,068)^{*}\end{array}$ & $\begin{array}{l}-0,587 \\
(0,037)^{\star *}\end{array}$ \\
\hline PD & $\begin{array}{c}-3.649 \\
(0,000)^{\star \star \star}\end{array}$ & $\begin{array}{c}-1,774 \\
(0,003)^{\star \star \star}\end{array}$ & $\begin{array}{c}-1,331 \\
(0,043)^{\star *}\end{array}$ & $\begin{array}{c}-2,271 \\
(0,004)^{\star \star \star}\end{array}$ & $\begin{array}{c}1,341 \\
(0,259) \\
\end{array}$ \\
\hline Urb & $\begin{array}{c}6.357 \\
(0,000)^{\star * *}\end{array}$ & $\begin{array}{c}3,367 \\
(0,001)^{\star * *}\end{array}$ & $\begin{array}{c}2,601 \\
(0,021)\end{array}$ & $\begin{array}{c}4,182 \\
(0,001)^{\star * *}\end{array}$ & $\begin{array}{c}2,433 \\
(0,078)^{*}\end{array}$ \\
\hline ESE & $\begin{array}{c}-0.290 \\
(0,002)^{* * *}\end{array}$ & $\begin{array}{c}-0,113 \\
(0,045)^{\star *}\end{array}$ & $\begin{array}{c}-0,232 \\
(0,005)^{\star * *}\end{array}$ & $\begin{array}{l}-0,054 \\
(0,385)\end{array}$ & $\begin{array}{c}-1,368 \\
(0,095)^{*}\end{array}$ \\
\hline CD & $\begin{array}{c}-1,614 \\
(0,000)^{\star \star \star}\end{array}$ & & & & \\
\hline Open & & $\begin{array}{c}0,250 \\
(0,000)^{\star \star \star}\end{array}$ & & & \\
\hline IM_GDP & & & $\begin{array}{c}0,640 \\
(0,000)^{\star \star \star}\end{array}$ & & \\
\hline EX_GDP & & & & $\begin{array}{c}0,498 \\
(0,006)^{\star \star \star}\end{array}$ & \\
\hline VRER & & & & & $\begin{array}{c}0,790 \\
(0,009)^{\star \star \star}\end{array}$ \\
\hline C (Intercept) & $\begin{array}{l}-50.258 \\
(0,073)^{\star}\end{array}$ & $\begin{array}{c}-29,805 \\
(0,189)\end{array}$ & $\begin{array}{r}-13,171 \\
(0.605)\end{array}$ & $\begin{array}{r}-45,362 \\
(0,105)\end{array}$ & $\begin{array}{l}35,758 \\
(0,611)\end{array}$ \\
\hline $\mathrm{R}^{2}$ & 0,7991 & 0,8586 & 0.8200 & 0,8083 & 0,7895 \\
\hline Wu-Hausman & 0,0178 & 0,0833 & 0,0381 & 0,0479 & 0,0006 \\
\hline Sargan & 0,6412 & 0,1180 & 0,6881 & 0,2148 & 0,9725 \\
\hline Basmann & 0,6814 & 0,1546 & 0,6902 & 0,2401 & 0,9758 \\
\hline
\end{tabular}

\section{Notes:}

1. Dependent variables: (1): Total tax revenues as a percentage of GDP ; (2) Income tax revenue/GDP; (3) : Corporate tax revenue/GDP; (4) Value added tax revenue/GDP; (5) : Trade tax revenue /GDP.

2. (.): In brackets are the probabilities of the estimators.

3. Significance levels: ${ }^{* \star *} 1 \%$; ${ }^{* *} 5 \% ;{ }^{*} 10 \%$

4. Used estimator: 2SLS (Two-Stage least squares).

5. Transmission channels for trade openness: CD; Open; IM_GDP; EX_GDP; VRER

Source: Elaboration of authors 
Table 3 : Trade openness and Trade tax revenue

\begin{tabular}{|c|c|c|c|c|c|}
\hline \multicolumn{6}{|c|}{$\begin{array}{l}\text { The dependent variable: Trade tax revenue/GDP } \\
\text { Estimator: } 2 \text { SLS }\end{array}$} \\
\hline Specifications & (1) & (2) & (3) & (4) & (5) \\
\hline LogGDP & $\begin{array}{l}16,210 \\
(0,133)\end{array}$ & $\begin{array}{c}5.146 \\
(0,119)\end{array}$ & $\begin{array}{c}5,677 \\
(0,207)\end{array}$ & $\begin{array}{c}3,715 \\
(0,199)\end{array}$ & $\begin{array}{c}2,402 \\
(0,286)\end{array}$ \\
\hline Agr_GDP & $\begin{array}{c}-0,245 \\
(0,066)^{*}\end{array}$ & $\begin{array}{l}-0,075 \\
(0,132)\end{array}$ & $\begin{array}{c}-0,079 \\
(0,085)^{\star}\end{array}$ & $\begin{array}{l}-0,060 \\
(0,281)\end{array}$ & $\begin{array}{l}-0,017 \\
(0,746)\end{array}$ \\
\hline Ind_GDP & $\begin{array}{c}0,060 \\
(0,585)\end{array}$ & $\begin{array}{c}0,070 \\
(0,389)\end{array}$ & $\begin{array}{c}0,087 \\
(0,259)\end{array}$ & $\begin{array}{c}0,033 \\
(0,708)\end{array}$ & $\begin{array}{l}-0,065 \\
(0,515)\end{array}$ \\
\hline PD & $\begin{array}{c}-0,832 \\
(0,000)^{\star \star *}\end{array}$ & $\begin{array}{c}-0,875 \\
(0,000)^{\star * *}\end{array}$ & $\begin{array}{c}-0,977 \\
(0,000)^{\star * \star}\end{array}$ & $\begin{array}{c}-0,680 \\
(0,000)^{\star * *}\end{array}$ & $\begin{array}{c}-0,930 \\
(0,000)^{\star * *}\end{array}$ \\
\hline Urb & $\begin{array}{c}1,230 \\
(0,000)^{\star * *}\end{array}$ & $\begin{array}{c}1,522 \\
(0,000)^{\star * *}\end{array}$ & $\begin{array}{c}1,669 \\
(0,000)^{\star \star \star}\end{array}$ & $\begin{array}{c}1,243 \\
(0,000)^{\star \star *}\end{array}$ & $\begin{array}{c}1,488 \\
(0,000)^{\star \star \star}\end{array}$ \\
\hline ESE & $\begin{array}{c}-0,117 \\
(0,000)^{\star * *}\end{array}$ & $\begin{array}{c}-0,108 \\
(0,000)^{\star *}\end{array}$ & $\begin{array}{c}-0,107 \\
(0,000)^{\star \star \star}\end{array}$ & $\begin{array}{c}-0,104 \\
(0,000)^{\star * *}\end{array}$ & $\begin{array}{l}-0,050 \\
(0,331)\end{array}$ \\
\hline CD & $\begin{array}{c}-0,448 \\
(0,044)^{\star \star}\end{array}$ & & & & \\
\hline Open & & $\begin{array}{c}-0,036 \\
(0,012)^{\star \star \star}\end{array}$ & & & \\
\hline IM_GDP & & & $\begin{array}{c}-0,058 \\
(0,005)^{\star \star \star}\end{array}$ & & \\
\hline EX_GDP & & & & $\begin{array}{c}-0,095 \\
(0,047)^{\star \star}\end{array}$ & \\
\hline $\begin{array}{l}\text { VRER } \\
\end{array}$ & & & & & $\begin{array}{c}-0,073 \\
(0,089)^{\star}\end{array}$ \\
\hline C (Intercept) & $\begin{array}{c}-163,996 \\
(0,017)^{\star \star \star}\end{array}$ & $\begin{array}{c}-65,447 \\
(0,002)^{\star * *}\end{array}$ & $\begin{array}{c}-72,653 \\
(0,000)^{\star \star *}\end{array}$ & $\begin{array}{c}-48,290 \\
(0,022)^{\star *}\end{array}$ & $\begin{array}{l}-43,102 \\
(0,061)^{\star}\end{array}$ \\
\hline $\mathrm{R}^{2}$ & 0,8842 & 0,9410 & 0,9500 & 0,9178 & 0,9058 \\
\hline Wu-Hausman & 0,0515 & 0,0002 & 0,0364 & 0,0003 & 0,0019 \\
\hline Sargan & 0,1517 & 0,3324 & 0,1004 & 0,1095 & 0,1346 \\
\hline Basmann & 0,1745 & 0,4048 & 0,1405 & 0,1518 & 0,1941 \\
\hline & & cance: * & $\begin{array}{l}5 \% ;{ }^{*} \\
\text { probabil }\end{array}$ & & \\
\hline
\end{tabular}

\section{Notes:}

1. Dependent variables: (1): Total tax revenues as a percentage of GDP ; (2) Income tax revenue/GDP; (3) : Corporate tax revenue/GDP; (4) Value added tax revenue/GDP; (5) : Trade tax revenue /GDP.

2. (.): In brackets are the probabilities of the estimators.

3. Significance levels: ${ }^{* *} 1 \%$; ${ }^{* *} 5 \%$; ${ }^{*} 10 \%$

4. Used estimator: 2SLS (Two-Stage least squares).

5. Transmission channels for trade openness: CD; Open; IM_GDP; EX_GDP; VRER

Source: Elaboration of authors

\subsection{Discussion of research hypotheses}

- The effect of customs duties : Hypothesis 1 
We note from the estimates made that customs duties have a significant negative effect on the entire Moroccan tax structure. This estimate mainly confirms the work of Khattry and Rao (2002). Trade liberalization, induced by the reduction of customs duties, reduces the amount of foreign trade revenue; and this, consequently, brings about a reduction in total tax revenue.

The negative relationship between customs duties and VAT is logical as customs tariffs are deducted on all import operations. VAT on imports is part of the taxable base of duties; therefore, a decrease in duties systematically leads to a decrease in VAT on imported products. We see this in specification (3) where a $1 \%$ increase in the import/GDP ratio leads to a $0.058 \%$ decrease in trade revenues.

The negative relationship between customs duties and tax revenues is explained by the increase in charges on certain importing companies. It can also be due to the increase in the price of raw materials, and the periods of depreciation of the national currency; which reduces selling prices and possibly profit margins. This situation also reduces the tax base of the corporate tax. However, the relationship between customs duties and the income tax base is not demonstrated. This is mainly because the taxable base for income tax is mainly made up of salaries, which are not directly related to customs duties.

\section{- The effect of imports : Hypothesis 2}

It should be noted that the reduction in customs duties did not have a proportional impact on tax revenues. It was accompanied by an increase in both imports and exports which, then, partially compensated for it in terms of tax revenues. Indeed, econometric modeling reveals that the import/GDP and export/GDP ratios have a positive and significant impact on domestic revenue. The impact, however, remains small. On the other hand, the impact on foreign trade revenues is statistically negative.

As for domestic revenues (ITR, CIT, and VAT), they are positively affected by the import/GDP ratio via the import demand channel. In fact, the behavior of imports reflects, to a large extent, the economic activity and, thus, the domestic tax revenues. Conversely, the negative effect on trade revenues is explained by several factors, mainly free trade agreements, exemptions, the weight of the informal sector, and the imperfect competition between firms.

\section{- The effect of exports : Hypothesis 3}

Economic theory suggests that trade openness increases the state's domestic tax revenues through two transmission channels: economic growth and export revenues. However, in Morocco, trade opening has a weak or even negligible impact on economic growth; and export revenues are quite low given the low quality of the exportable offer. In terms of modeling, even though the export/GDP ratio has a significant and positive impact on domestic revenues, this does not support the above theoretical observation. In other words, the positive effect is not explained by trade openness and its favorable channels on the tax base.

We can explain the positive influence of the export-to-GDP ratio on domestic revenue by the tax contribution of exporting firms in terms of corporate tax and the declaration of income tax and 
VAT. Nevertheless, while this contribution is described as unfair given that multinationals benefit much more from tax advantages, small entrepreneurs are penalized by heavy taxation.

Thus, the modeling results indicate that the share of exports in GDP has a negative effect on tax revenues from foreign trade. In fact, Morocco is not an oil-exporting country and does not have strong natural resources. Consequently, it is normal that export revenues, and therefore trade revenues, are not expected. Even though the rate of openness is very high, we affirm that the problem lies in the quality of the Moroccan exportable offer.

- The effect of variability in the real effective exchange rate: Hypothesis 4

Modeling results reveal that while the effect of exchange rate variability is significantly negative on trade revenues, it is positive on domestic tax revenues, including CIT, ITR, and VAT. These results reveal the impact of exchange rate devaluation policies. The latter has a favorable effect on overall economic activity, and it, thus, causes the increase in domestic tax revenues. Certainly, devaluation increases the value of imported products, which becomes more expensive, and this is reflected in lower trade taxes. As a result, the consumption of tradable goods becomes more expensive and will switch to non-tradable goods. This, as a matter of fact, reflects an increase in both local demand and domestic tax revenues.

\subsection{Discussion of the effect of control variables}

This part presents in detail the estimated effect of the control variables on the structure of Moroccan tax revenues.

- The effect of GDP per capita

The estimated models have again corroborated our theoretical findings [Lotz and Morss (1967); Chelliah (1971)]. GDP per capita, as a development indicator and proxy for the contributive capacity of citizens in terms of taxation, has a strong positive relationship with the structure of tax revenues and is statistically significant.

The positive impact of GDP per capita on the VAT tax rate is plausible. In other words, the more production there is, the higher the level of consumption, and, consequently, the higher the VAT due. As for income tax, it is highly correlated with GDP per capita. This proves that the Moroccan economy generates tax revenue through the strong contribution of citizens.

Concerning foreign trade revenues, GDP per capita is statistically insignificant. This result is explained by the orientations of the public authorities which seek to stimulate foreign trade (the signing free trade agreements, dismantling of tariffs, etc.). Moreover, the insignificant relationship between GDP per capita and trade revenues is sometimes associated with the poor international economic situation in terms of rising prices for tradable goods. This asserts that people lack the purchasing power to acquire and consume goods and services imported from abroad. Consequently, this causes and a lack of trade revenues. This situation allows policy-makers to focus on taxation on domestic revenues.

- The effect of sector composition 
The shortfall in terms of tax revenues in the agricultural sector is explained by its large share in the Moroccan economy. The estimate shows that the added value of the agricultural sector has a significantly negative impact on the total tax rate. This result is due to the predominance of substantial agricultural activity and the weight of exemptions. Moreover, the results of the modeling were surprising. Countries with a higher share of agriculture benefit from a large percentage of income tax. However, the estimation was able to show that the contribution of agriculture to income tax revenues is negative, which is explained by the low wages (SMIG and SMAG) and the unemployment rate in this pluviometric situation in such a vulnerable sector. The negative effect of agriculture on income tax revenues is linked to the underperformance of the sectoral strategy called "Green Morocco Plan". This strategy, which has been implemented for years, is unable to create jobs. Thus, the increase in unemployment in the agricultural sector reduces income tax revenues. Also, agricultural products do not contribute to international trade revenues; there is a lack of statistical significance in this regard. This fiscal demobilization is explained by the weakness of the exportable supply of Moroccan agricultural non-competative products, and relations with EU countries. These two aspects are of political and economic nature.

The results of the econometric estimation also show that the industry does not contribute to the structure of fiscal revenues. This result is partly explained by the tax exemptions granted to the industrial sector and the exemptions on the various branches of industry. Thus, entrepreneurship in Morocco is characterized by its rent insofar as less than $1 \%$ of companies pay corporate income tax (CIT). Moreover, income tax revenues are not affected by the Moroccan industry. Indeed, business income tax is more affected by tax evasion and fraud. At the level of trade revenues, the industry has no effect. This observation is explained by the weakness of Morocco's global professions. Tthe latter remain concentrated on small segments, mainly cabling.

- The effect of population density

Population density has a negative effect on the tax structure. In Morocco, the areas are characterized by the absence of development plans, which pushes citizens towards the informal sector. This situation increases the taxation costs of the tax administration in terms of tax control and audit (the fight against tax evasion and fraud). As a result, the pace of tax collection will be very low.

\section{- The effect of urbanization}

As previous studies suggest, tax revenues increase as a society becomes more urbanized. The estimation results show that urbanization has a positive impact on tax revenues. It is argued that urbanization increases both the need for tax revenues and the capacity to tax. On the demand side, increased urbanization leads to an increased need for public services. On the supply side, urbanization leads to higher tax bases as economic activity tends to be concentrated in urban areas. However, the phenomenon of urbanization remains connected to the most dynamic Moroccan cities such as Casablanca, Rabat, Tangier, and Marrakech.

- The effect of the secondary school enrolment rate 
The secondary school enrolment variable is a proxy variable for the informal economy, the level of education, and the quality of public provision in the education sector. This variable shows a negative and significant sign. This result is explained by the fact that people do not comply with their tax obligations as there is a lack of financial knowledge and quality of public goods and services offered by the government in the educational sector. Furthermore, the "secondary school enrolment rate" variable suggests that as these people turn to informal activities to express their needs, fiscal demobilization is generated as a result.

\section{Conclusion}

Trade liberalization has many effects on economic, political, and social change in developing countries. The fiscal impact of trade liberalization is one of them. It is becoming increasingly important for developing economies to seriously consider the trade liberalization impact as most of these economies have largely opened their borders without assessing the fiscal consequences.

The main objective of this study is to empirically assess the impact of trade openness on the structure of Moroccan tax revenues over the period 1985-2019. More specifically, this work attempts to study the effects of lower tariffs, import liberalization, export promotion, and exchange rate variability on the Moroccan tax structure.

Using these indicators to measure trade openness, the results of the modeling, using the 2SLS method, confirm our main hypothesis that a reduction in customs duties has a negative impact on foreign trade revenues, and, consequently, on total tax revenues. Similarly, a reduction in tariffs leads to a decrease in VAT revenues because import VAT is part of the tax base of tariffs. As a result, we are witnessing a systematic decrease in VAT on any operation subject to the declaration of imported VAT. Thus, the negative effect of customs duties on corporate tax revenue is explained by the increase in charges on certain importing firms, which has a negative impact on selling prices and possibly profit margins.

Besides, the two ratios of imports to GDP and exports to GDP have a significant negative impact on foreign trade revenues. On the import side, this can be explained by free trade agreements, the large share of the informal sector, exemptions, and imperfect competition between firms. On the export side, the negative effect is due to the weakness of the Moroccan exportable offer, the absence of the favorable impact of openness on economic growth, the application of non-tariff duties by Morocco's trading partners, and the low level of export revenues.

On the other hand, the aforementioned ratios have a positive and significant effect on domestic tax revenues. The positive relationship between the share of imports in GDP and domestic revenue is attributed to the import demand channel. This demand reflects a good level of economic activity, and therefore a fiscal collection of domestic revenue. Concerning the share of exports in GDP, the positive effect is not associated with the fruits of trade openness, but with the fiscal contribution of exporting firms.

With regard to exchange rate variability, the latter reveals a negative effect on trade revenues. However, it is positive on domestic revenues. These two opposite effects are attributed to the devaluation policy. The above-mentioned policy has increased the value of imports. The latter has become expensive and changed the behavior of consumers who move towards the consumption 
of non-tradable goods in exchange for tradable goods. As a result, we are witnessing a fiscal mobilization of domestic revenues against a fiscal demobilization of trade revenues.

As for the effects of the control variables, these corroborate our theoretical postulates. GDP per capita is positively related to domestic revenues and negatively related to foreign trade revenues. The shortfall in revenue in the agricultural and industrial sectors can be explained by the preponderant share of agriculture and the informal sector in the Moroccan economy, tax exemptions, and derogations. The density of the population is negatively linked with the structure tax. This result is due to the absence of development plans in densely populated areas. Urbanization has a positive influence on the structure of tax revenues, but it remains concentrated on the most urbanized cities. The negative effect of the variable schooling rate on the tax structure indicates the presence of tax non-compliance with taxpayers. The latter do not respect their fiscal commitments as there is a lack of quality in the public offer, especially in the educational sector.

Statistically, the estimation technique using the 2SLS method was able to show the robustness of our estimators. The Wu-Hausman test confirms the endogeneity status of the indicators of trade openness. Similarly, Sargan's test asserts the validity of the instruments associated with the proxy variables of the variable geographical characteristics of Morocco's bilateral trade.

Considering the importance of the results of the modeling and stylized facts, we can deduce certain findings related to the fiscal impact of trade liberalization. The efforts made by the Moroccan public authorities to stimulate foreign trade have led to a loss of trade revenue. The reduction of customs tariffs changes the Moroccan tax structure by moving away from international taxation and by compensating for the loss of trade taxes by increasing income and consumption taxes. These observations clearly illustrate the fiscal injustice between taxpayers.

\section{Recommendations:}

Our work suggests some implications that economic decision-makers should implement in the context of trade liberalization. One of which is to appropriate tax reform considering the challenges of trade opening. Also, challenging the use of tariffs is surely an important step in improving the trade tax base. Also, working on developing the quality of the Moroccan exportable offer is essential.

\section{Future perspective:}

This work can be further enriched through considering the role played by the institutional quality. There is a whole theoretical debate on the importance of institutions as a channel of transmission, which favorably reinforces the effect of the opening up of trade on the tax structure, in general, and trade taxes, in particular.

\section{References}

Ahmad, Khalil \& Ali, Safdar. 2018. Trade Liberalization-Trade Revenue Nexus: An Empirical Enquiry of Trade Laffer Curve of Pakistan. Sukkur IBA Journal of Management and Business. vol. 5(1), pages 66-84. DOI:10.30537/sijmb.v5i1.190 
Agbeyegbe, T. D., Stotsky, J. and WoldeMariam, A. 2006. "Trade liberalization, exchange rate changes, and tax revenue in Sub-Saharan Africa ». Journal of Asian Economics, $17 \mathrm{n}^{\circ} 2$ : 261-284. DOl: $\underline{10.1016 / j . a s i e c 0.2005 .09 .003}$

Addison, T. and Levin, J. 2006. "Tax Policy Reform in Developing Countries». Third draft 2006-06-17, WIDER.

Bornhorst, F, Gupta, S, and Thornton, J. 2009. "Natural Resource Endowments and the Domestic Revenue Effort ». European Journal of Political Economy, vol 25, №4, 439-446. DOI: $\underline{10.1016 / j . e j p o l e c o .2009 .01 .003}$

Baunsgaard, Thomas and Michael Keen. 2005. " Tax revenue and (or ?) trade liberalization ». IMF Working Paper WP/05/112.

Baunsgaard, T. and Kenn, M. 2009, " Revenue and (or ?) Trade Liberalisation ». Journal of Public Economics, 94, 563-577. DOI: 10.1016/i.jpubeco.2009.11.0007

Bahal, Roy. 2003. "Reaching the Hardest to Tax : Consequences and Possibilities ». Paper presented at the 'Hard to Tax : An International Prespective' conference, : May 15-16. Andrew Young School of Policy Studies, Georgia State University.

Drummond P. et al. 2012. "Mobilizing Revenue in Sub-saharan Africa : Empirical Norms and Key Determinants ». Internationa Monetary Fund, Working Paper n¹2/108. DOI: 10.5089/9781475503296.001

Ebrill, L., Stotsky J., and Gropp R., 1999. « Revenue Implications of Trade Liberalisation ». IMF Occasional Paper 90/20 Washington : International Monetary Fund.

Epaphra, M. 2014. The Revenue Implications of Trade Liberalization in Tanzania. World Economic Research, 3(10), 25-36. DOI: 10.11648/i.jwer.20140303.12

Frankel, Jeffrey, A., and David H. Romer. 1999. " Does Trade Cause Growth? ». American Economic Review, 89 (3): 379-399. DOI: 10.1257/aer.89.3.379

Hatzipanayoton, P, Michael, M, S., and Miller, S, S. M. 1994. "Win-win indirect tax reform a modest proposal ». Economics Letters, 44(1), 147-151. DOI: 10.1016/0165-1765(93)00315-F

Hisali, E. 2012. "Trade policy reform and international trade tax revenue in Yganda ". Economic Modelling, 29 : 2144-2154. DOI: 10.1016/i.econmod.2012.06.033

Joshua Aizenman and YothinJinjarak. 2009. "Globalisation and Developing Countries - a Shrinking Tax Base ? ». Journal of Development Studies, Vol.45, N.5, PP: 653-671. DOI: $\underline{10.1080 / 00220380802582338}$

Karimi Mohammad, Shivee Ranjanee Kaliappan, Normaz Wana Ismail and Hanny Zurina Binti Hamzah. 2016. Does Trade Liberalization Affects International Trade Tax Revenue ? Evidence From Dynamic Panel Threshold Method. Economic Studies journal, 5(1), 75-87. DOI: oai:psasir.upm.edu.my:55564

Khattry, B., Rao, M.J. 2002. "Fiscal Faux Pas ? : An analysis of the revenue implications of trade liberalization ». World Development, 30, n 8 : 1431-1444. DOI: 10.1016/S0305-750X(02)00043-8 
Khattry, B., 2003. "Trade Liberalization and the Fiscal Squeeze : Implications for Public Investment ». Development and Change 34(3) : 401-424. DOI: 10.1111/1467-7660.00312

Keen, Michael, Ligthart, jenny. 2002. "Coordinating tariff reductions and domestic tax reform ». Journal of International Economics, 56, 407-425. DOI: 10.1016/S0022-1996(01)00123-4

Keen, Michael and Alejandro Simone. 2004. «Tax Policy in Developing Countries : Some Lessons from the 1990s, and Some Challenges Ahead ». IMF Working paper, 62/83.

Longoni, E., 2009. « Trade Liberalization and Trade Tax Revenues in African Countries », Working Paper Series, $\mathrm{N}^{\circ}, 158$.

Lotz, J.R. and Morss, E.R.. 1970. "A Theory of Tax Level Determinants for Developing Countries ». Economic Development and Cultural Change, 18, 328-341. DOI:10.1086/450436

Othieno, L. and Shinyekwa, I. 2011. «Trade, Revenue and Welfare Effects of The East African Community Customs Union Principale of Asymmetry on Uganda : An Application of Wits-Smart Simulation Model ». Economic Policy Research Centre (EPRC), Research Series 150480. DOI: 10.22004/ag.econ.150480

Rodriguez, F. and Rodrik, D. 1999. "Trade Policy and Economic Growth : A Skeptic's Guide to the CrossNational Literature ». NBER Working Paper 70/81. DOI: 10.1086/654419

Rodrik, Dani,. 1999. " The New Global Economy and Developing Countries: Making Openness Work », Washington, DC, Overseas Development Council, (1999a). DOI: 10.1002/10991328(200007)12:53.0.CO;2-L

Stotsky J G and WoldeMariam, A. 1997. «Tax effort in Sub-Sahran Africa ». IMF Working Paper, 97(107).

Sèna Kimm Gnangnon. 2017. "Multilateral Trade Liberalisation and Government Revenue ». Journal of Economic Integration, vol 32, N³, PP :586-614. DOI: 10.11130/jei.2017.32.3.586

Tanzi, V. 1987. "Quantitative Characteristics of the Tax Systems of Developing Countries ». In The Theory of Taxation for Developing Countries, edited by David Newbery and Nicholas Stern : Oxford University Press for the World Bank, New York, 205?241.

UNECA. 2004. « Economic Report on Africa ». United Nations Economic Commission for Africa, Annual report 2004, Addis Ababa. 


\section{Appendix}

Appendix 1: Correlation matrix of variables

\begin{tabular}{|c|c|c|c|c|c|c|c|c|c|c|c|c|c|c|c|}
\hline & TTR_GDP & CIT_GDP & ITR_GDP & VAT_GDP & TRD_GDP & LGDP & Agr_GDP & Ind_GDP & $\mathrm{PD}$ & Urb & ESE & $\mathrm{CD}$ & Open & IM_GDP & EX_G \\
\hline TTR_GDP & 1 & & & & & & & & & & & & & & \\
\hline ITR_GDP & 0,94 & 1 & & & & & & & & & & & & & \\
\hline CIT_GDP & 0,93 & 0,96 & 1 & & & & & & & & & & & & \\
\hline VAT_GDP & 0,85 & 0,86 & 0,92 & 1 & & & & & & & & & & & \\
\hline TRD_GDP & $-0,53$ & $-0,65$ & $-0,69$ & $-0,83$ & 1 & & & & & & & & & & \\
\hline LogGDP & 0,86 & 0,89 & 0,89 & 0,91 & $-0,79$ & 1 & & & & & & & & & \\
\hline Agr_GDP & $-0,51$ & $-0,61$ & $-0,53$ & $-0,59$ & 0,60 & $-0,51$ & 1 & & & & & & & & \\
\hline Ind_GDP & $-0,56$ & $-0,52$ & $-0,51$ & $-0,46$ & 0,10 & $-0,53$ & 0,05 & 1 & & & & & & & \\
\hline PD & 0,85 & 0,86 & 0,85 & 0,87 & $-0,74$ & 0,98 & $-0,52$ & $-0,56$ & 1 & & & & & & \\
\hline Urb & 0,85 & 0,85 & 0,84 & 0,86 & $-0,71$ & 0,97 & $-0,50$ & $-0,58$ & 0,99 & 1 & & & & & \\
\hline ESE & 0,78 & 0,82 & 0,83 & 0,88 & $-0,87$ & 0,96 & $-0,54$ & $-0,39$ & 0,94 & 0,93 & 1 & & & & \\
\hline CD & $-0,84$ & $-0,90$ & $-0,90$ & $-0,93$ & $-0,95$ & $-0,96$ & 0,63 & 0,41 & $\begin{array}{c}- \\
0,93 \\
\end{array}$ & $-0,92$ & $\begin{array}{c}- \\
0,95 \\
\end{array}$ & 1 & & & \\
\hline Open & 0,83 & 0,88 & 0,89 & 0,95 & $-0,86$ & 0,92 & $-0,66$ & $-0,29$ & 0,88 & 0,87 & 0,92 & $\begin{array}{c}-95 \\
0,95\end{array}$ & 1 & & \\
\hline IM_GDP & 0,83 & 0,86 & 0,89 & 0,96 & $-0,88$ & 0,91 & $-0,64$ & $-0,27$ & 0,86 & 0,85 & 0,91 & $\begin{array}{c}- \\
0,94\end{array}$ & 0,99 & 1 & \\
\hline EX_GDP & 0,79 & 0,87 & 0,85 & 0,89 & $-0,85$ & 0,92 & $-0,67$ & $-0,33$ & 0,90 & 0,88 & 0,91 & $\begin{array}{c}- \\
0,94 \\
\end{array}$ & 0,98 & 0,94 & 1 \\
\hline VRER & 0,63 & 0,67 & 0,62 & 0,71 & $-0,76$ & $-0,52$ & 0,13 & $-0,35$ & $\begin{array}{c}- \\
0,01\end{array}$ & $\begin{array}{c}- \\
0,001\end{array}$ & $\begin{array}{c}- \\
0,30\end{array}$ & $\begin{array}{c}- \\
0,58 \\
\end{array}$ & $-0,53$ & $-0,68$ & $-0,70$ \\
\hline
\end{tabular}

Appendix 2: Standard descriptive statistics on the variables used in the analysis

\begin{tabular}{|l|c|c|c|c|c|}
\hline \multicolumn{1}{|c|}{ Variable } & Observations & Mean & $\begin{array}{c}\text { Standard } \\
\text { deviation }\end{array}$ & Minimum & Maximum \\
\hline TTR_GDP & 35 & 23.54 & 3.84 & 15.89 & 31.25 \\
\hline ITR_GDP & 35 & 6.73 & 1.93 & 2.71 & 11.21 \\
\hline CIT_GDP & 35 & 3.13 & 1.43 & 1.11 & 6.45 \\
\hline VAT_GDP & 35 & 5.89 & 1.80 & 3.16 & 8.82 \\
\hline TRD_GDP & 35 & 2.53 & 1.20 & 0.61 & 2.26 \\
\hline LogGDP & 35 & 9.79 & 0.26 & 9.36 & 10.19 \\
\hline Agr_GDP & 35 & 13.54 & 1.74 & 10.86 & 18.43 \\
\hline Ind_GDP & 35 & 26.29 & 1.09 & 24.23 & 30.20 \\
\hline PD & 35 & 66.19 & 9.02 & 50.49 & 81.72 \\
\hline Urb & 35 & 54.24 & 5.12 & 44.77 & 62.93 \\
\hline ESE & 35 & 50.50 & 16.42 & 30.48 & 79.30 \\
\hline CD & 35 & 8.66 & 5.38 & 1.73 & 15.35 \\
\hline Open & 35 & 64.49 & 14.25 & 47.09 & 88.10 \\
\hline IM_GDP & 35 & 35.96 & 8.86 & 25.14 & 50.19 \\
\hline EX_GDP & 35 & 28.65 & 5.73 & 20.93 & 39.45 \\
\hline VRER & 35 & 101.45 & 4.65 & 92.50 & 111.84 \\
\hline
\end{tabular}


Appendix 3: The channels of transmission of the trade openness

\begin{tabular}{|c|c|c|}
\hline Channels of transmission & Definition & Note \\
\hline $\begin{array}{l}\text { Trade openness, percent } \\
\text { of GDP }\end{array}$ & $\begin{array}{l}\text { The evolution of the size of international trade have } \\
\text { two opposing effects on taxes. On the one hand, } \\
\text { greater openness of trade should make it possible to } \\
\text { reduce taxes levied on imports and exports following } \\
\text { the signing of free trade agreements, tariff } \\
\text { dismantling,.. etc., between countries. On the other } \\
\text { hand, since the greater openness of trade is } \\
\text { associated with higher rates of economic growth, } \\
\text { and therefore, increased mobilization of tax } \\
\text { revenues. }\end{array}$ & Open \\
\hline $\begin{array}{l}\text { The rate of customs } \\
\text { duties }\end{array}$ & $\begin{array}{l}\text { Customs duties are all taxes imposed on goods. In } \\
\text { other words, They are levied on the import and } \\
\text { export of goods. A reduction in customs duties } \\
\text { reduces the amount of trade revenue as well as total } \\
\text { tax revenue. }\end{array}$ & CD \\
\hline $\begin{array}{l}\text { The share of imports in } \\
\text { GDP }\end{array}$ & $\begin{array}{l}\text { Import liberalization is measured by the IM / GDP } \\
\text { ratio. This is a channel transmission as the state can } \\
\text { generate tax revenue from an import demand. The } \\
\text { level of import demand reflects the level of economic } \\
\text { activity, and hence an increase in the tax base. }\end{array}$ & IM_GDP \\
\hline $\begin{array}{l}\text { The share of exports in } \\
\text { GDP (the export effort) }\end{array}$ & $\begin{array}{l}\text { Export promotion is measured by the EX/GDP ratio. } \\
\text { It is a channel transmission of trade openness as the } \\
\text { government can collect revenues through exportable } \\
\text { supply and economic growth. }\end{array}$ & EX_GDP \\
\hline $\begin{array}{l}\text { Variability of the real } \\
\text { effective exchange rate }\end{array}$ & $\begin{array}{l}\text { The variability of the exchange rate is also a channel } \\
\text { transmission. Indeed, the devaluation of the } \\
\text { exchange rate generates a reduction in trade taxes. } \\
\text { This devaluation makes imports very expensive, } \\
\text { hence the passage to domestic demand, and } \\
\text { consequently, an increase in domestic revenues. }\end{array}$ & VRER \\
\hline
\end{tabular}


Appendix 4: Results of econometric models

Table 1 : Trade openness and VAT tax revenue

\begin{tabular}{|c|c|c|c|c|c|}
\hline \multicolumn{6}{|c|}{$\begin{array}{l}\text { The dependent variable: VAT tax revenue /GDP } \\
\text { Estimator: 2SLS }\end{array}$} \\
\hline Specifications & (1) & (2) & (3) & (4) & (5) \\
\hline LogGDP & $\begin{array}{r}-10.749 \\
(0.500)\end{array}$ & $\begin{array}{c}9.856 \\
(0,001)^{\star * *}\end{array}$ & $\begin{array}{c}8.835 \\
(0.010)^{* * *}\end{array}$ & $\begin{array}{c}12.815 \\
(0.002)^{* * *}\end{array}$ & $\begin{array}{c}15.904 \\
(0.000)^{\star * *}\end{array}$ \\
\hline Agr_GDP & $\begin{array}{c}0,219 \\
(0.432)\end{array}$ & $\begin{array}{l}-0,092 \\
(0.271)\end{array}$ & $\begin{array}{l}-0,085 \\
(0.254)\end{array}$ & $\begin{array}{l}-0,118 \\
(0.251)\end{array}$ & $\begin{array}{c}-0,220 \\
(0.022)^{* *}\end{array}$ \\
\hline Ind_GDP & $\begin{array}{c}0,182 \\
(0.429)\end{array}$ & $\begin{array}{l}0,133 \\
(0.333)\end{array}$ & $\begin{array}{c}0,099 \\
(0.431)\end{array}$ & $\begin{array}{c}0,208 \\
(0.208)\end{array}$ & $\begin{array}{c}0,448 \\
(0.013)^{* *}\end{array}$ \\
\hline PD & $\begin{array}{l}-0,699 \\
(0.102)\end{array}$ & $\begin{array}{c}-0,588 \\
(0.019)^{\star * *}\end{array}$ & $\begin{array}{l}-0,367 \\
(0.127)\end{array}$ & $\begin{array}{c}-1.044 \\
(0,001)^{\star \star \star}\end{array}$ & $\begin{array}{l}-0,436 \\
(0.293) \\
\end{array}$ \\
\hline Urb & $\begin{array}{c}1.396 \\
(0.044)^{* *}\end{array}$ & $\begin{array}{c}0,800 \\
(0.036)^{* *}\end{array}$ & $\begin{array}{l}0,476 \\
(0.185)\end{array}$ & $\begin{array}{c}1.456 \\
(0,005)^{\star * *}\end{array}$ & $\begin{array}{c}0,865 \\
(0.095)^{*}\end{array}$ \\
\hline ESE & $\begin{array}{c}-0,037 \\
(0,000)^{* * *}\end{array}$ & $\begin{array}{c}-0,053 \\
(0.036)^{\star *}\end{array}$ & $\begin{array}{c}-0,055 \\
(0.014)^{\star \star *}\end{array}$ & $\begin{array}{c}-0,061 \\
(0.059)^{* *}\end{array}$ & $\begin{array}{c}-0,193 \\
(0.048)^{\star *}\end{array}$ \\
\hline CD & $\begin{array}{c}-0,877 \\
(0.059)^{\star *}\end{array}$ & & & & \\
\hline Open & & $\begin{array}{c}0,083 \\
(0.001)^{\star \star \star}\end{array}$ & & & \\
\hline IM_GDP & & & $\begin{array}{c}0,130 \\
(0,000)^{\star \star \star}\end{array}$ & & \\
\hline EX_GDP & & & & $\begin{array}{c}0,228 \\
(0.009)^{\star \star \star}\end{array}$ & \\
\hline VRER & & & & & $\begin{array}{c}0,180 \\
(0.168)\end{array}$ \\
\hline C (Intercept) & $\begin{array}{l}83.359 \\
(0.563)\end{array}$ & $\begin{array}{c}-99.991 \\
(0,005)^{\star * *}\end{array}$ & $\begin{array}{c}-85.445 \\
(0.011)^{\star * *}\end{array}$ & $\begin{array}{c}-136.813 \\
(0.000)^{\star * *}\end{array}$ & $\begin{array}{c}-148.58 \\
(0.000)^{\star \star \star}\end{array}$ \\
\hline $\mathrm{R}^{2}$ & 0.7749 & 0.9261 & 0.9419 & 0.8782 & 0.8646 \\
\hline Wu-Hausman & 0.0105 & 0.0001 & 0.0183 & 0.0000 & 0.0469 \\
\hline Sargan & 0.0628 & 0.2278 & 0.6783 & 0.4916 & 0.1343 \\
\hline Basmann & 0.0955 & 0.2981 & 0.7200 & 0.5506 & 0.1938 \\
\hline
\end{tabular}

Source: Authors' elaboration based on estimates 
Table 2 : Trade openness and Corporate income tax revenue

\begin{tabular}{|c|c|c|c|c|c|}
\hline \multicolumn{6}{|c|}{$\begin{array}{l}\text { The dependent variable: Corporate income tax revenue /GDP } \\
\text { Estimator: } 2 S L S\end{array}$} \\
\hline Specifications & (1) & (2) & (3) & (4) & (5) \\
\hline LogGDP & $\begin{array}{c}13,829 \\
(0.060)^{*}\end{array}$ & $\begin{array}{c}16.132 \\
(0,000)^{* * *}\end{array}$ & $\begin{array}{c}16.196 \\
(0.000)^{\star * *}\end{array}$ & $\begin{array}{c}17.004 \\
(0.000)^{\star * \star}\end{array}$ & $\begin{array}{c}17.839 \\
(0.000)^{\star \star \star}\end{array}$ \\
\hline Agr_GDP & $\begin{array}{c}0,044 \\
(0.578)\end{array}$ & $\begin{array}{c}-0,185 \\
(0.004)^{* * \star}\end{array}$ & $\begin{array}{c}-0,193 \\
(0.002)^{\star \star \star}\end{array}$ & $\begin{array}{c}-0,179 \\
(0.021)^{\star *}\end{array}$ & $\begin{array}{c}-0,225 \\
(0.026)^{* *}\end{array}$ \\
\hline Ind_GDP & $\begin{array}{l}-0,060 \\
(0.654)\end{array}$ & $\begin{array}{l}-0,038 \\
(0.717)\end{array}$ & $\begin{array}{l}-0,039 \\
(0.699)\end{array}$ & $\begin{array}{l}-0,017 \\
(0.880)\end{array}$ & $\begin{array}{l}0,207 \\
(0.299)\end{array}$ \\
\hline PD & $\begin{array}{c}-0,816 \\
(0.003)^{\star * *}\end{array}$ & $\begin{array}{c}-0,884 \\
(0.000)^{* * *}\end{array}$ & $\begin{array}{c}-0,795 \\
(0.000)^{* * *}\end{array}$ & $\begin{array}{c}-1.161 \\
(0,000)^{* * *}\end{array}$ & $\begin{array}{l}-0,530 \\
(0.289)\end{array}$ \\
\hline Urb & $\begin{array}{c}1.330 \\
(0.004)^{\star * *}\end{array}$ & $\begin{array}{c}1.110 \\
(0.000)^{\star \star *}\end{array}$ & $\begin{array}{c}0,973 \\
(0.001)^{\star * *}\end{array}$ & $\begin{array}{c}1.522 \\
(0,000)^{\star * *}\end{array}$ & $\begin{array}{c}1.050 \\
(0.049)^{\star *}\end{array}$ \\
\hline ESE & $\begin{array}{c}-0,064 \\
(0.017)^{\star \star *}\end{array}$ & $\begin{array}{c}-0,091 \\
(0.000)^{\star * *}\end{array}$ & $\begin{array}{c}-0,093 \\
(0.000)^{\star * *}\end{array}$ & $\begin{array}{c}-0,094 \\
(0.000)^{\star * *}\end{array}$ & $\begin{array}{c}-0,264 \\
(0.058)^{\star *}\end{array}$ \\
\hline CD & $\begin{array}{c}-0,553 \\
(0.000)^{\star \star \star}\end{array}$ & & & & \\
\hline Open & & $\begin{array}{c}0,043 \\
(0.027)^{\star \star}\end{array}$ & & & \\
\hline IM_GDP & & & $\begin{array}{c}0,060 \\
(0.023)^{\star *}\end{array}$ & & \\
\hline EX_GDP & & & & $\begin{array}{c}0,152 \\
(0.065)^{\star}\end{array}$ & \\
\hline VRER & & & & & $\begin{array}{c}0,237 \\
(0.048)^{\star \star}\end{array}$ \\
\hline C (Intercept) & $\begin{array}{l}-5.954 \\
(0.506)\end{array}$ & $\begin{array}{l}-151.173 \\
(0.000)^{\star * *}\end{array}$ & $\begin{array}{l}-149.325 \\
(0.000)^{\star * *}\end{array}$ & $\begin{array}{c}-165.73 \\
(0.000)^{\star * *}\end{array}$ & $\begin{array}{l}-158.302 \\
(0.001)^{\star \star \star}\end{array}$ \\
\hline $\mathrm{R}^{2}$ & 0.8476 & 0.9326 & 0.9367 & 0.9108 & 0.7804 \\
\hline Wu-Hausman & 0.0124 & 0.0076 & 0.0368 & 0.0554 & 0.0461 \\
\hline Sargan & 0.2113 & 0.5981 & 0.5739 & 0.4827 & 0.5724 \\
\hline Basmann & 0.2816 & 0.6483 & 0.6639 & 0.5423 & 0.6250 \\
\hline
\end{tabular}

Source: Authors' elaboration based on estimates 
Table 3 : Trade openness and Income tax revenue

\begin{tabular}{|c|c|c|c|c|c|}
\hline \multicolumn{6}{|c|}{$\begin{array}{l}\text { The dependent variable: Income tax revenue /GDP } \\
\text { Estimator: } 2 S L S\end{array}$} \\
\hline Specifications & (1) & (2) & (3) & (4) & (5) \\
\hline LogGDP & $\begin{array}{c}16,422 \\
(0.023)^{\star \star}\end{array}$ & $\begin{array}{c}16.987 \\
(0,000)^{\star \star \star}\end{array}$ & $\begin{array}{c}17.814 \\
(0.045)^{\star \star}\end{array}$ & $\begin{array}{c}17.541 \\
(0.010)^{* * *}\end{array}$ & $\begin{array}{c}16.071 \\
(0.072)^{*}\end{array}$ \\
\hline Agr_GDP & $\begin{array}{l}-0,129 \\
(0.195)\end{array}$ & $\begin{array}{l}-0,168 \\
(0.091)^{\star}\end{array}$ & $\begin{array}{l}-0,120 \\
(0.268)\end{array}$ & $\begin{array}{l}-0,198 \\
(0.069)^{*}\end{array}$ & $\begin{array}{c}-0,295 \\
(0.014)^{* * *}\end{array}$ \\
\hline Ind_GDP & $\begin{array}{l}-0,224 \\
(0.179)\end{array}$ & $\begin{array}{c}-0,517 \\
(0.002)^{\star * *}\end{array}$ & $\begin{array}{c}-0,603 \\
(0.001)^{\star * *}\end{array}$ & $\begin{array}{c}-0,452 \\
(0.015)^{\star * \star}\end{array}$ & $\begin{array}{l}-0,279 \\
(0.246)\end{array}$ \\
\hline PD & $\begin{array}{c}-0,841 \\
(0.013)^{\star * *}\end{array}$ & $\begin{array}{l}-0,195 \\
(0.499)\end{array}$ & $\begin{array}{l}0,016 \\
(0.956)\end{array}$ & $\begin{array}{l}-0,483 \\
(0.181)\end{array}$ & $\begin{array}{l}-0,265 \\
(0.534)\end{array}$ \\
\hline Urb & $\begin{array}{c}1.412 \\
(0.012)^{\star * *}\end{array}$ & $\begin{array}{l}0,371 \\
(0.452) \\
\end{array}$ & $\begin{array}{l}0,023 \\
(0.965) \\
\end{array}$ & $\begin{array}{l}0,835 \\
(0.166) \\
\end{array}$ & $\begin{array}{c}0,011 \\
(0.209) \\
\end{array}$ \\
\hline ESE & $\begin{array}{c}-0,079 \\
(0.016)^{\star \star *}\end{array}$ & $\begin{array}{l}-0,023 \\
(0.393)\end{array}$ & $\begin{array}{c}-0,057 \\
(0.080)^{*}\end{array}$ & $\begin{array}{r}-.00042 \\
(0.988)\end{array}$ & $\begin{array}{l}-0,072 \\
(0.585)\end{array}$ \\
\hline CD & $\begin{array}{c}-0,597 \\
(0.000)^{\star \star \star}\end{array}$ & & & & \\
\hline Open & & $\begin{array}{c}0,112 \\
(0.000)^{\star \star}\end{array}$ & & & \\
\hline IM_GDP & & & $\begin{array}{c}0,234 \\
(0.000)^{\star \star \star}\end{array}$ & & \\
\hline EX_GDP & & & & $\begin{array}{c}0,252 \\
(0.002)^{\star \star \star}\end{array}$ & \\
\hline VRER & & & & & $\begin{array}{c}0,133 \\
(0.056)^{\star \star}\end{array}$ \\
\hline C (Intercept) & $\begin{array}{c}2.649 \\
(0.811)\end{array}$ & $\begin{array}{c}9.358 \\
(0.394)\end{array}$ & $\begin{array}{l}16.345 \\
(0.162)\end{array}$ & $\begin{array}{c}3,405 \\
(0.009)^{\star * *}\end{array}$ & $\begin{array}{c}18.365 \\
(0.081)^{*}\end{array}$ \\
\hline $\mathrm{R}^{2}$ & 0.8716 & 0.8685 & 0.8493 & 0.8402 & 0.7895 \\
\hline Wu-Hausman & 0.0733 & 0.0192 & 0.0305 & 0.0021 & 0.0058 \\
\hline Sargan & 0.3155 & 0.6693 & 0.0935 & 0.2051 & 0.5160 \\
\hline Basmann & 0.3995 & 0.7069 & 0.1245 & 0.2645 & 0.5708 \\
\hline
\end{tabular}

Source: Authors' elaboration based on estimates 